\title{
FREED BONDED LABOUR IN THE FAR WESTERN TARAI
}

\author{
Narad Awasthi, PhD \\ Associate Professor \\ Department of Geography Education \\ Tribhuvan University, Kirtipur
}

\begin{abstract}
The bonded labourers (Kamaiyas) were mostly from the indigenous Tharu ethnic group, who are still socially and economically disadvantaged. They have been surviving on the agricultural labour practice for centuries in the mid and far western Tarai of Nepal. This paper concentrates on the socio-economic and demographic background and means of livelihood of the freed Kamaiyas in Kanchanpur district of the far western development region of Nepal. For study purpose, 55 heads of household were selected from Krishnapur, Daijee VDCs and Bhimdatta municipality. All of them were from the Tharu community. They were from 20-55 years of age group and average age of the freed Kamaiyas was 38 years. Educational background was unsatisfactory and they all were married. The Kamiyas were not well settled from the side of government. Therefore, they were compelled to change their continuous means of livelihood. The study shows that they have been employed in different sectors of economic activities. Agriculture wage labour, share cropping, non-agriculture wage labour, government and private services within and outside the country, carpentry, masonry and many other types of occupation have been conducted by the freed labour (Kamaiyas) in the study area. They were economically in the worst condition and the average income was only NRs 3400 per month. They have raised some concerning issues viz landlessness, education, employment and rehabilitation.
\end{abstract}

Key words: Bonded labour, feudal, indebtedness, jhara, kamaiyas, kamlhari, livelihood, slavery

\section{The Context}

Nepal is a landlocked mountainous country with immense diversity of caste/ethnicity and cultures. It consists of a multilingual multi-religious and multi-ethnic society. Among the 103 caste/ethnic groups, the Tharu of the Hindu caste is considered an indigenous community which is still socially, economically and educationally deprived and marginalized. It is evident that the Tharus have been surviving on agricultural labour for centuries. They have occupied only 6.75 percent share in the total population of Nepal (CBS, 2001) These Tharus of the Tarai region have been working as the bonded labourers (kamaiyas) in the house of landlords. The overwhelming majority of the bonded labours are from the Tharu ethnic group (Awasthi, 2005, Ojha, 1982). The Tharu bonded labourers are mainly concentrated in the Tarai region of Nepal and they constitute more than 98 percent of the total Kamaiyas (INSEC 1990). The vast majority of labourers are from the native community of the mid and far western Tarai religions of Nepal. This native group used to transmit bondage from one generation to another (Subedi 1999). The Tharus had emigrated from India during the Muslim invasion in the twelfth century. They are identified as two groups namely Dangaura and Rana Tharu. The Dangaura Tharus migrated from Korbang of Dang and Rana Tharus have been settled in the western
Tarai region (Jnawali, 1999). The Tharus have densely been settled in Kanchanpur, Kailai, Bardiya, Banke and Dang district of the mid and far western development regions of Nepal.

The Kamaiya practice is a residual part of a feudal system prevailing in the Nepali society for centuries. This system is a form of slavery prevalent in our country as well as neighboring countries (Lamichhane, 2005). The slavery is not a new phenomenon for Nepal. It has been deeply rooted from Lichchhvi to Rana regime and still it is alive. Slavery is the outcome of caste system and appaulling poverty among the people.

The King Jayasthiti Malla introduced caste system in the fourteenth century in Nepal and the same practice has been continuing in the Hindu society (Sharma, 1951). There are a number of forms of slavery continuing in our Nepali society. Such types of slave workers are known as Haliya, Haruwa, Kamaiya, Kamlahari, Kamlhar, Jan, Gothala, Khetala, Charuwa, Gaibar and Bhainsbar or Chebar.

The history of Nepal is an eyewitness on different kinds of exploitation of poor people in this country. Porters and labourers were provided 10 paisa per day as wages fixed in 1965 B.S. which was similar to the forced or unpaid labourers 'Jhara' (Regmi, 1971). Forced labour practice was the aftermath of ownership on land and increased demand of labour. 
The bulk of cultivated land was occupied by Birta grants and Jagir assignment. The army officials, Chautariyas, Bhardars, Kajis, Royal priests and Gurus and royal families' relatives were provided forced and unpaid labour 'Jhara' Bethi and Begari for agricultural activities (Regmi, 1988). The then government was not able to pay wages to the large number of porters and labourers. However, unpaid labourers were emancipated in 1937 A.D. As a consequence, slave labourers were engaged in domestic service spheres. Property rights of the land were not to the majority of the peasants. Money lenders compelled the peasants to work for them under bondage system. Thus the indebtedness was the most causal factor of slavery which has been deeply roted and still continuing in the socioeconomic fabric of the Nepali society.

The slavery was abolished by Prime Minister Chandra Samsher Rana, in 1925 A.D. However, it could not bring any change. The exploitation of poor people continued in various forms. The bonded labourers were also freed in 17 July 2000. But their problems and issues are not still addressed by the government of Nepal. The bonded labourers were provided with one Kattha of land per family for homestead but in practice, they have been proclaiming to have landlessness or sukumbashis. They have created a serious problem by encroaching land wherever the public and government land is found to be vacant.

This paper attempts to deal with the recent means of livelihood with demographic and socio-economic conditions of the freed bonded labourers settled in the study area of the far Western Tarai, Nepal.

\section{Materials and Methods}

The study area is Kanchanpur district in the far western development region of Nepal. The district covers an area of $1610 \mathrm{~km}^{2}$. According to the population census 2001, the total population of the district is 377,899 (CBS, 2001). This district comprises of 19 Village Development Committees (VDCs) and one municipality of 19 wards with a population of 80939 persons. Most of its population is concentrated in the plain area, a narrow passage of the Bhaber lying between the proper Tarai and Siwalik range. The Mahakali is the main river originated from Api and Saipal range of the western Himalaya and other temporary rivers are originated from the Siwalik range. This area has tropical and sub-tropical climate. The indigenous Tharus have been settling there since the unrecorded history. The migrants having varied castes and cultures have been emigrating from different places of the hills after the eradication of endemic malaria in the study area.

The paper is mainly concentrated on primary sources of data collected from Kanchanpur district for the study of socio-economic conditions and current means of livelihood of the bonded labourers (Kamaiyas) after their emancipation in the study area. For this study, only 55 household heads were purposively sampled for interview from two Village Development Committees and Bhim Datla Municipality where the freed Kamaiyas have settled in shelters provided by the government of Nepal and somewhere they have encroach the public and government land. Of the total respondents, 40 percent were carried out from ward no. 2 of in Bani of Krishnapur VDC, 30 selected from ward No. 5 of Daijee VDC, about 30 percent respondents were selected from ward No. 4 of Nimbukheda in Bhim Datta Municipality of the study area. Majority of the bonded labourers were settled in Bani village Forty percent were covered for interview and equal size of samples were selected from Daijee and municipality.

In addition to this, focus group discussion, individual contact and observation techniques were also adopted. Some key informants were also consulted for necessary information about the bounded labour settled in the study area. Some useful materials were also collected from different articles, theses, magazines, project reports and journals published.

\section{Results and Discussions}

\section{Socio-economic and Demographic Characteristics}

This section explains socio-economic and demographic characteristics of the sampled freed bonded labour. The main focus is provided on age and sex, marital status, educational background, occupations and economic condition of the freed Kamaiyas settled in the study area.

Age and Sex Composition: Age and sex are considered as the vital components of population in the study area. The total sampled population of the Kamaiyas was 364 . Of them, 51 percent were females whereas 49 percent males. The sex ratio is found 957 per thousand. In terms of the age structure about 33 percent were below 15 years of age and 61 percent were between 16 to 60 years of age and the remaining 6 percent were above 60 years (Table 1). Dependency ratio is observed 39 percent of the sampled population of the freed Kamaiyas. 
Table 1: Age and Sex of the Kamaiyas

\begin{tabular}{|l|c|c|c|c|c|c|}
\hline \multirow{2}{*}{ Age group } & \multicolumn{2}{|c|}{ Female } & \multicolumn{2}{c|}{ Male } & \multicolumn{2}{c|}{ Total } \\
\cline { 2 - 7 } & Number & Percent & Number & Percent & Number & Percent \\
\hline $0-15$ & 63 & 33.9 & 58 & 32.6 & 121 & 33.2 \\
\hline $16-60$ & 111 & 59.7 & 110 & 61.8 & 221 & 60.6 \\
\hline Over 60 & 12 & 6.4 & 10 & 5.6 & 22 & 6.1 \\
\hline Total & 186 & 100.0 & 178 & 100.0 & 364 & 100.0 \\
\hline
\end{tabular}

Source: Field study, 2012

Distribution of Kamaiyas by Age: The data on distribution of bonded labourers by age are discussed in table 2. Of the Kamaiyas, 22 percent were found between 41 to 45 years age and followed by 16 percent of 31 to 35 years of age group. Similarly, about 14 percent were observed to have 26 to 30 years of age and 14.5 percent were of $46-50$ years of age group. Moreover, 12.7 percent from $20-25$ and 36 to 40 years of both age group and the rest 7.3 percent were above from 50 years of age. The average age of the bonded labourers computed was 38 years (Table 2).

Table 2: Distribution of the bonded labour by age group

\begin{tabular}{|l|c|c|}
\hline Age group & Number & Percent \\
\hline $20-25$ & 7 & 12.7 \\
\hline $26-30$ & 8 & 14.5 \\
\hline $31-35$ & 9 & 16.4 \\
\hline $36-40$ & 7 & 12.7 \\
\hline $41-45$ & 12 & 21.8 \\
\hline $46-50$ & 8 & 14.6 \\
\hline $51-55$ & 4 & 7.3 \\
\hline Total & 55 & 100.00 \\
\hline
\end{tabular}

Source: Field survey, 2012

Educational Background: The educational standard of the bonded labourers was investigated to be worse off. Out of the total, about 43 percent were found illiterate. Out of this, 56 percent were females. About 26 percent were just literate in which 22 percent were females. Among them only 12 percent were found to have passed primary level and 10 percent had passed middle school. Moreover, 6 percent were observed SLC test pass and only 3 percent found to have passed higher education in the study area (Table 3)

Table 3: Educational back ground of the bonded labour
Marital Status: The freed Kamaiyas, who were interviewed, were all married. Of them, 10 percent heads of household were widowed or separated. Their family size computed is 6.4. About 27 percent were married at the age of below 15 years and 66 percent were observed to be married between 16 to 20 years of age group. Moreover, only 7 percent were married between 20 - 25 years of age group.

Occupational Composition: The Kamaiyas were engaged in the agricultural farms of the landowners' family. They were hard working, obedient and honest persons. Their sincerity, devotion and energetic nature led them to be the Kamaiyas (bonded labour) for years. In the late 1950s, malaria eradication programme was launched; the hill people were migrated to the Tarai region. At that time, many people earned land by encroaching and buying from the Tharus in low cost. The Tharus were found as a cheap labourer, who could work hard in the malarial Tarai. The landlords gradually made them honest and loyal and bonded them to work in their fields (Pyakuryal, 1982).

After the restoration of democracy in 1990, most of the deprived and marginalized ethnic groups raised their voice and as a result, the Kamaiyas were emancipated. The then government of Nepal freed the Kamaiyas but proper settlement was not undertaken. The scenario regarding the freed Kamaiyas changed. They had to seek new means of livelihood for their survival. They were compelled to change their previous jobs and were employed in various sectors of economic activities within and outside the country. The majority of the Kamaiyas have been employing in agricultural activities as wage labourers. A large number of Kamaiyas, near about 27 percent of the total, have been involved

\begin{tabular}{|l|c|c|c|c|c|c|}
\hline \multirow{2}{*}{ Educational background } & \multicolumn{2}{|c|}{ Total } & \multicolumn{2}{c|}{ Female } & \multicolumn{2}{c|}{ Male } \\
\cline { 2 - 7 } & Number & Percent & Number & Percent & Number & Percent \\
\hline illiterate & 136 & 43.0 & 81 & 56.6 & 55 & 31.4 \\
\hline Literate & 82 & 26.00 & 32 & 22.4 & 50 & 28.6 \\
\hline Primary & 40 & 12.00 & 11 & 7.7 & 29 & 16.6 \\
\hline Middle & 32 & 10.0 & 10 & 7.0 & 22 & 12.6 \\
\hline Text & 19 & 6.0 & 6 & 4.2 & 13 & 7.4 \\
\hline SLC and Plus & 9 & 3.0 & 3 & 201 & 6 & 3.4 \\
\hline Total & 318 & 100.00 & 143 & 100.0 & 175 & 100.0 \\
\hline
\end{tabular}

Source: Field survey, 2012 
in agricultural wage labour. It is followed by nonagricultural wage labour which shares 10 percent of the total.

About 8.6 percent Kamaiyas were employed in private jobs in different sectors within country. Only 8.6 percent have been employed abroad especially in India. Moreover, 8 percent labourers are involved in carpentry work whereas 7 percent are engaged in masonry at local and district level. About 7 percent labourers have been employing in share-cropping. Similarly, 5.3 percent of the Kamaiyas have been engaged in pastoral activities whereas 4.3 percent were involved in petty business. About 3.8 are engaged at Rickshaw pulling in market areas and the same 3.8 percent are employed at government services in Nepal. In addition, 3.3 percent is found to be employed in domestic service and only 2.4 percent are engaged in others job in the study area (Table 4).

\section{Table 4: Means of livelihood of the freed Kamaiyas}

\begin{tabular}{|l|c|c|}
\hline \multicolumn{1}{|c|}{ Occupation } & Population & Percent \\
\hline Agriculture wage labour & 57 & 27.0 \\
\hline $\begin{array}{l}\text { Non-agricultural wage } \\
\text { labour }\end{array}$ & 21 & 10.0 \\
\hline Service in private sectors & 18 & 8.6 \\
\hline Service to India & 18 & 8.6 \\
\hline Carpentry & 17 & 8.0 \\
\hline Share cropping & 15 & 7.0 \\
\hline Masonry & 15 & 7.0 \\
\hline Animal husbandry & 11 & 5.3 \\
\hline Petty-business & 9 & 4.3 \\
\hline Rickshaw puller & 8 & 3.8 \\
\hline $\begin{array}{l}\text { Government service in } \\
\text { Nepal }\end{array}$ & 8 & 3.8 \\
\hline Domestic service & 7 & 3.3 \\
\hline Others & 209 & 100.0 \\
\hline Total
\end{tabular}

Source: Field survey, 2012.

The means of livelihood of the freed Kamaiyas are varying or diversified. They diversified their livelihoods because single source of income was not sufficient for survival. Nepal is predominantly an agricultural country and the livelihood strategies are highly oriented to agricultural activities.

Income Level: The freed Kamaiyas are engaged in diverse economic activities to sustain their life in better way after the emancipation from bonded labour. The diverse activities are marked by varying degree of success according to their access to varied resources (Awasthi, 2011). The income of the Kamaiyas is not satisfied due to their change of occupation and break of continuity. However, the table 5 shows that about 11 percent households earn
Rs from 1000 to 2000 and 23.6 percent achieve Rs 2000 to 3000 per month. About 31 percent earn Rs. 3000 to 4000 and 16.4 percent achieve Rs between 4000 and 5000. Moreover, 5.4 percent labour earn Rs between 5000 and 6000 and 7.2 percent earn Rs. between 6000 and 4000 . The remaining 5.5 percent households earn Rs. between 7000 to 8000 and over 8000 per month in the study area Kanchanpur. The average income is computed NRS. 3400.

Table 5: Income of the freed Kamaiyas per month

\begin{tabular}{|l|c|c|}
\hline \multicolumn{1}{|c|}{ Income (Rs 000) } & Respondents & Percent \\
\hline $1-2$ & 6 & 10.9 \\
\hline $2-3$ & 13 & 23.6 \\
\hline $3-4$ & 17 & 31.0 \\
\hline $4-5$ & 9 & 16.4 \\
\hline $5-6$ & 3 & 5.4 \\
\hline $6-7$ & 4 & 7.2 \\
\hline $7-8$ & 2 & 3.7 \\
\hline 8 above & 1 & 1.8 \\
\hline Total & 55 & 100.00 \\
\hline
\end{tabular}

\section{Conclusion}

Nepal is a country of diverse caste/ethnic cultures. Among caste/ethnic groups, the Tharu as an indigenous tribe is being predominant in the Tarai. These Tharus have been facing varied problems associated with bonded labour before and after its abolition. After the installation of democracy in 2007 and 2046 B.S., some improvements have been executing in term of bonded labour from Kamaiyas to other domestic servants kamalhari, gothala, Bukrahi and kamlars but the freed Kamaiyas are not well settled in a proper way. These freed labourers are encroaching public land wherever they find to be vacant. They are claiming to have landlessness. About one kattha of land was provided by the government of Nepal but it was not sufficient for large families of the Kamaiyas.

The Kamaiyas were born in bondage and lifelong they were under slavery. This system is a remnant of the old feudalism where poor, simple and ignorant people have been exploited by the clever and rich ones. The Kamaiyas are not well in educational background; dependency is 39 percent and average age of the Kamaiyas is observed to be 38 years. After emancipation, they were compelled to seek new means of livelihood for survival. As a consequence, they have been employing in diverse sectors of economic activities such as: agricultural wage labour, non agricultural wage labour, service within and outside the country, share cropping, carpentry, masonry and animal husbandry and others. Their monthly income is very low. The result of the study manifests that the socio economic conditions of the 
freed labour is deplorable. Due to non-effectiveness programmes of resettlement, some freed Kamaiyas may prefer to return to the system of bondage. It is recommended that the Kamaiyas and other forms of slavery must be emancipated and the victims should be provided adequate means to generate income of their own to survive as a human being.

\section{References}

Awasthi, N. (2011). Labour migration to Nainital: A situational analysis Perspectives on Higher Education, 6, 131-138.

Awasthi, N. (2005). Demographic and socio-economic characteristics of migrants: A study of Kanchanpur district in far western Tarai of Nepal. Unpublished doctoral dissertation, Department of geography, Kumaun University, Nainital, India.

CBS (2002). Population census, 2001. National report. Kathmandu: CBS.

INSEC (1996). Nepal ma Kamaiya pratha bhitra bandha majdur. Kathmandu: INSEC.

Jnawali, D. (1999). The Tharus of Bardia district in Nepal Tarai: A study of ecological and population perspectives. Unpublished doctoral dissertation, Banaras Hindu University, Varanasi, India.

Lamichhane, P.R. (2006). Bonded labour in Nepal. Kathmandu: Trilij Counseling Centre.

Ojha, D. P. (1982). Planned and spontaneous land settlement in Nepal: A study of two Tarai settlements in Kanchanpur district. PhD Dissertation, Cornell University, USA.

Pyakuryal, K. (1982). Ethnicity and rural development: A sociological study of four Tharu villages in Chitwan, Nepal, PhD Dissertation, Michigan State University, USA.

Regmi, M. C. (1971). A study in Nepal economic history 1768-1846. Delhi: Manjusri.

Regmi, M. C. (1988). An economic history of Nepal. Banaras: Nath Publishing House.

Sharma, B. C. (1951). Nepal ko itihasik ruprekha (in Nepali). Banaras: Nath Publishing House.

Subedi, T. P. (1999) Bonded labour in Nepal: A sociological study of Kamaiya system in Khairi Chandanpur VDC of Bardiya district, Unpublished Master's thesis, Tribhuvan University, Kathmandu. 